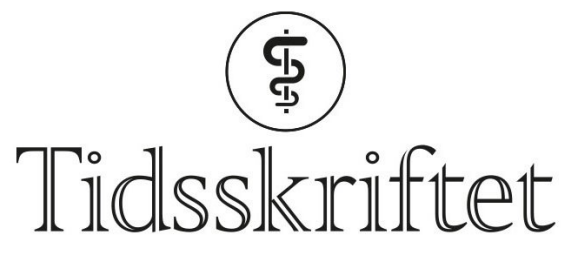

DEN NORSKE LEGEFORENING

\title{
DNA-reparasjon har en nevroprotektiv funksjon
}

FRA ANDRE TIDSSKRIFTER

RUTH HALSNE

Tidsskriftet

Mekanismer bak aldringsprosesser kan avdekke nye terapeutiske mål for Alzheimers sykdom.

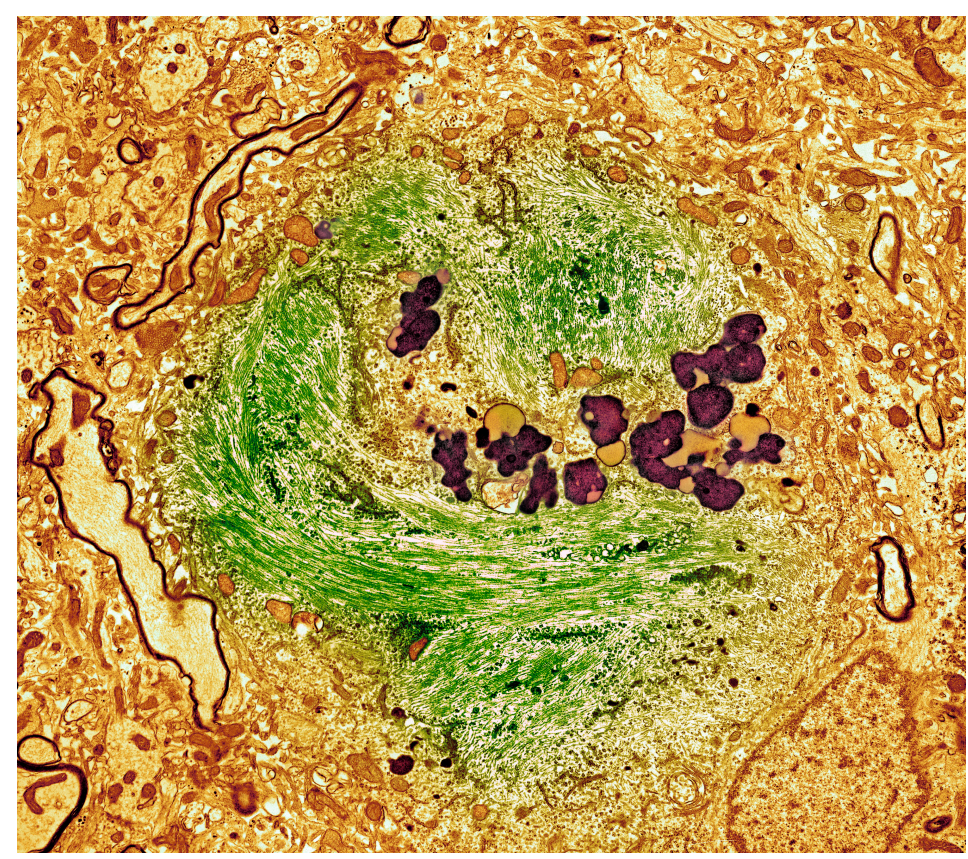

Farget transmisjonselektronmikroskopisk bilde av en nevofibrillcer floke i en nervecelle fra hjernen til en pasient med Alzheimers sykdom. Illustrasjonsfoto: Science Photo Library

Flere nevrodegenerative sykdommer, bl.a. Alzheimers sykdom, ser ut til å være knyttet til akkumulering av DNA-skade. SIRT6-protein, en histonedeacetylase (HDAC) som er involvert i DNA-reparasjon, kan være en nøkkel til å forstå hva som skjer.

I en studie med mus, der SIRT6-protein var fjernet fra hjernen, ble det påvist en akselererende aldringsprosess og $ø$ kende forekomst av DNA-skader i form av dobbelttrådbrudd (1). Mengden av tauprotein, en markør for Alzheimers sykdom, var forhøyet i cortex, men ikke i hippocampus. Tauproteinet er i seg selv ikke skadelig, men posttranslasjonelle modifikasjoner som fosforylering eller acetylering kan stabilisere proteinet og føre til danning av toksiske aggregater. 
Cellestudier viste at GSK3-kinase, som kan fosforylere tauproteinet, responderte på økt mengde DNA-skader som igjen responderer på lave SIRT6-nivåer. Analyser av mRNA og proteinnivå i cortex hos pasienter med Alzheimers sykdom viste en reduksjon av SIRT6protein som samsvarte med alvorlighetsgraden av sykdommen.

- SIRT6-proteinet ser ut til å være viktig for å holde genomet stabilt i hjernen, sier Ole A. Andreassen, som er professor ved Universitetet i Oslo og forsker på demensgenetikk. - Ved redusert mengde SIRT6-protein oppstår en skadelig fosforylering og stabilisering av tauprotein.

- Denne studien viser hvordan man kan studere sykdomsmekanismer i dyremodeller. Pasienter med Alzheimers sykdom viste en reduksjon av SIRT6-nivået, målt post mortem. Funnene kan danne grunnlaget for utviklingen av nye medikamenter som hindrer opphopningen av DNA-skader, og på den måten hemme utviklingen av Alzheimers sykdom. Som ved annen behandling av nevrodegenerative lidelser vil det viktigste være å komme til med behandling før sykdommen har kommet for langt, sier Andreassen.

\section{LITTERATUR:}

1. Kaluski S, Portillo M, Besnard A et al. Neuroprotective functions for the histone deacetylase SIRT6. Cell Reports 2017; 18:3052 - 62. [PubMed][CrossRef]

Publisert: 28. november 2017. Tidsskr Nor Legeforen. DOI: 10.4045/tidsskr.17.09oo

(C) Tidsskrift for Den norske legeforening 2020. Lastet ned fra tidsskriftet.no 